Györi Gábor \& Hegedüs Irén:

A metonímia és a metafora mint a perspektivikus kategorizáció formái a lexikalizációban

és a grammatikalizációban

Argumentum 17 (2021), 275-293

Debreceni Egyetemi Kiadó

DOI: 10.34103/ARGUMENTUM/2021/15

Győri Gábor \& Hegedüs Irén

\title{
A metonímia és a metafora mint a perspektivikus kategorizáció formái a lexikalizációban és a grammatikalizációban
}

\begin{abstract}
Every linguistic expression reflects reality from some perspective. This perspectival view can manifest itself in different ways in language. One manifestation of this is that we do not necessarily find overlap of category scopes defined by expressions of similar meanings when comparing different languages. Perspectivity can also manifest itself in the semantic transparency of an expression when it reveals some metaphorical or metonymic interpretation of reality. Even in the case of expressions that are not transparent in this sense, perspectivity can be noted but only from a historical point of view. This transpires in the etymology of expressions through metaphorical or metonymic semantic changes that can also explain category differences between languages. In the present study, we discuss these various manifestations of perspectivization with respect to lexicalization and grammaticalization.

Keywords: perspective, categorization, metaphor, metonymy, lexicalization, grammaticalization, semantic change
\end{abstract}

\section{Bevezetés}

A kategorizáció funkciója a környezet egyedi jelenségeinek hasonló perceptuális jegyek alapján történö, és a környezettel való hatékony interakció szempontjából releváns csoportosítása. Ez elsősorban nem nyelvi folyamat, hanem egy általános, nem csak az emberre jellemző, az adaptív viselkedést irányító alapvető kognitív folyamat (Harnad 2005: 21; Singh \& Hoffman 2013: 172). Például egy egér számára a környezettel való hatékony interakciónak számít mindenféle macska elkerülése, mely viselkedést többek között a macskákra általánosan jellemző perceptuális jegyek felismerése és ezáltal az adott jelenség macskaként való azonosítása irányít. Azonban az ember nyelvi képessége lehetővé teszi, hogy környezetünket ne csak perceptuális alapokon kategorizáljuk még akkor sem, amikor fizikális, tárgyi jelenségekről van szó. Például az angol cup szó esetében a bizonyos fajta ivóedényekre való referenciális használat kategorizációs alapját nem képezheti a pusztán perceptuális jegyek felismerése. Egy műanyag- vagy papírpohár ugyanúgy beletartozik a cup szó által kijelölt kategóriába, mint egy kerámia csésze, pedig a kétfajta ívóedény sem formájában sem anyagában nem hasonlít egymásra. Emellett még az a - természetesen percepciós jegyek alapján azonosítható - tulajdonságuk, hogy inni lehet 
Győri Gábor \& Hegedüs Irén:

A metonímia és a metafora mint a perspektivikus kategorizáció formái a lexikalizációban

és a grammatikalizációban

Argumentum 17 (2021), 275-293

Debreceni Egyetemi Kiadó

DOI: 10.34103/ARGUMENTUM/2021/15

belőlük, vagyis hogy ivóedényként használatosak, más tárgyakra is vonatkozik. Tehát a percepció alapján felismert funkciójuk, azaz affordanciájuk (Gibson 1979: 119), sem képezheti annak kizárólagos alapját, hogy egy kategóriába tartoznak.

A nyelv kognitív megközelítésében általános nézet, hogy a nyelv a tapasztalatok kulturális kategorizálásának eszköze, mely kategorizálás a valóságnak az emberi megismerés sajátos mechanizmusai alapján történő értelmezése is egyben (pl. Croft \& Cruse 2004: 74; Lakoff 1987: 8; Langacker 2013: 17; Tomasello 1999: 166). Rosch (1978: 28) ilyen értelemben beszél arról, hogy „a kategóriák kialakulása [...] egy kultúrában való kialakulásukat jelenti”, és hogy „egy kultúrában megtalálható kategóriák [...] a kultúra nyelve által egy adott időpontban kódolt kategóriák". ${ }^{1}$ A nyelvi kategorizálás a társas megismerést szolgálja, mert a kategóriáknak a beszélők egymás közötti átadása által valósul meg azok kulturális reprezentációja (Tomasello 2003: 51). A társas viselkedésben a nyelv „az információ szervezésének, feldolgozásának és továbbításának eszköze" (Geeraerts 1997: 6), de maga a társas megismerés képessége nem csak az ember sajátja (Quiatt \& Reynolds 1993: 141). A nyelv azonban a szimbolikus kogníció képességének megteremtése által a társas megismerést sokkal komplexebb formában teszi lehetővé.

A szimbólumok segítségével történő kommunikáció által a megismerés még hatékonyabbá válik rugalmasság és terjedelem tekintetében, mivel az egyén jelentős mértékben részesülhet és profitálhat mások, akár korábbi generációk tapasztalataiból és ismereteiből (Goodson 2003: 74; Győri 1996: 177; Harnad 2005: 37; Tomasello 1999: 8, 107). Tehát a nyelvi kategóriák egy beszédközösségnek a természeti és társadalmi-kulturális környezetéről alkotott azon közös ismereteit képviselik, amelyek ahhoz szükségesek, hogy a beszélők funkcionális és adaptív módon léphessenek interakcióba a környezetükkel. Ennek következtében ahhoz, hogy a nyelv mint kulturálisan meghatározott kognitív-kommunikatív rendszer hatékonyan elláthassa feladatát, a kategorizálásnak ezen interakciókhoz hasznos és szükséges perspektívákból kell tükröznie a környezetet (Tomasello 1999: 8-9). Ezért a nyelvi jelentésben megjelenő perspektívák az ennek megfelelö értelmezést szolgáló módon strukturálják a világot, és nem annak objektív leképezését közvetítik (Geeraerts 1997: 8).

Az a tény, hogy a világ jelenségeinek perspektivikus reprezentációja lényegi jellemzője a nyelvi jelentésnek, azért is alapvető, mert a környezet egy dinamikus rendszer, amelyben a körülmények és az alkotóelemek állandóan változnak (gyakran az interakciók következtében), ami maga után vonhatja az interakciók módozatainak változásait is. Emellett a világ értelmezését nem csak az objektív valóság megváltozása és annak a környezettel folytatott interakciókra való kihatása módosíthatja, hanem a már ismert jelenségek is feltünhetnek újszerü perspektívában a közösség kulturális valóságának és gondolkodásmódjának változása következtében (Tomasello 1999: 12). A nyelvnek lépést kell tartania ezekkel a változásokkal annak érdekében, hogy müködőképes kognitív-kommunikációs rendszer maradjon és teljesíteni tudja a társas megismerést szolgáló funkcióját. Másszóval a nyelvnek mindig alkalmazkodnia kell a beszélők kommunikációs és kognitív igényeihez abban a tekintetben, hogy miként tükrözi fizikai, társadalmi, kulturális, történelmi stb. környezetüket. Ezért a nyelvnek mint rendszernek elég rugalmasnak kell lennie ahhoz, hogy egyaránt igazodni tudjon a környezet ideiglenes (akár pillanatnyi) vagy maradandó kulturális jelentőségű változásaihoz, vagyis ezek következtében a közösség által együttesen felvett perspektívák módosulásaihoz (Bybee 2011: 78). Ez a rugalmasság a beszélők megismerési folyamataiban és mechanizmusaiban gyökerezik, aminek következtében a különböző környezetek különböző hatást gyakorolhatnak az egyes nyelvekre abban a tekintetben, hogy az

1 A szövegben található, nem magyarnyelvủ forrásokból származó idézeteket a szerzők fordították. 
Győri Gábor \& Hegedüs Irén:

A metonímia és a metafora mint a perspektivikus kategorizáció formái a lexikalizációban és a grammatikalizációban

Argumentum 17 (2021), 275-293

Debreceni Egyetemi Kiadó

DOI: $10.34103 / A R G U M E N T U M / 2021 / 15$

adott nyelv kategóriaszerkezete a beszélők által felvett perspektívákból fakadó kommunikációs és kognitív igényeknek megfelelően alakuljon. Tomasello (1999: 9) szerint a nyelvi szimbólumok olyan perspektivikus alapú kognitív reprezentációk, amelyek azt tükrözik, hogy a dolgok számos lehetséges értelmezése közül a beszélök melyik értelmezést választották. Ezért az ezekben a szimbólumokban megnyilvánuló kategorizáció alapja az emberi észlelésnek és tapasztalatnak az olyan képzeleti struktúrák segítségével történő értelmezése, mint a metafora és a metonímia (Johnson 1987: xi; Lakoff 1987: 8). A perspektívák tehát alapjában véve a metaforikus és metonimikus konceptualizációkban manifesztálódnak.

A megismerésnek a környezettel való interakciót irányító központi szerepe következtében már maga a percepció sem lehet egyszerủ objektív információgyüjtés a világról, hanem az interakció függvényében szelektív szürési folyamatként kell müködnie (Goodson 2003: 116, 263; Harnad 2005: 36; Langacker 1987: 101; Mark et al. 2010: 513-514; Singh \& Hoffman 2013: 172). Rosch (1978: 29) a kategorizáció alapelveinek (kognitív gazdaságosság és észlelt világszerkezet) meghatározásakor ezt úgy magyarázza, hogy azt, hogy a környezet milyen jellemzőit észleli a vele interakcióba lépő egyén, sok különböző tényező határozza meg annak függvényében, hogy számára a fizikai és társas környezettel való interakció során mely jellemzők a funkcionálisan szükségesek. A valóság ily módon történő értelmezését egy visszacsatolási mechanizmus szabályozza annak függvényében, hogy az milyen adaptív értékkel bír az érzékelő és a kategorizáló egyén számára (Harnad 2005: 26). De ezen túlmenően a perspektívát az is befolyásolhatja, hogy különböző alkalmakkor különböző interakciókra lehet szükség ugyanabban a környezetben, vagy ugyanaz az egyén különféle belső és külső tényezők hatására különböző interakciókkal reagálhat, ami által különböző perspektívákat vehet fel (ld. Kövecses és Benczes 2010: 151). Tomasello (1999: 8-9) szerint a nyelvi szimbólumokban megtestesülő kategorizációk azokat a perspektívákat tükrözik, amelyeket korábbi generációk beszélői több lehetséges perspektíva közül választottak a világ aktuális értelmezéséhez. Ez a választás, vagyis maga a perspektíva, attól függ, hogy az adott jelenségnek melyek a környezettel való megfelelő interakció szempontjából leginkább szembeszökő és legfontosabb tulajdonságai. A fent említett visszacsatolási mechanizmusnak természetesen a nyelvi kategóriák és jelentések kialakulásánál is müködnie kell.

A nyelvi szimbólumokban rejlő perspektivizáció különböző módokon jelenhet meg a nyelvben. A perspektivizáció egyik fontos megnyilvánulása az az általános jelenség, amikor a világ kategoriális felosztását nyelvek közötti összehasonlításban vizsgálva különböző eltéréseket találunk, vagyis a hasonló jelentésű kifejezések által kijelölt kategóriaterjedelmek között nem teljes az átfedés. Ezt látjuk például az angol table 'asztal' és a magyar asztal szavak közötti összehasonlításban, mivel a table szó a referensek szükebb körére utal, mert például egy íróasztal nem tartozik bele abba a kategóriába, amelyet a table szó kijelöl. ${ }^{2}$ A perspektivizáció egy másik megnyilvánulása, amikor egy kifejezés szemantikai áttetszősége jelez valamilyen perspektivikus látásmódot. A szemantikailag áttetsző nyelvi elemekben olyan módon mutatkozik meg a perspektivizáció, hogy ezekben az esetekben a megfigyelhető metaforizáció és metonimizáció a lexikalizáció kognitív aspektusairól árulkodik, vagyis arról, hogy mi az a perspektíva,

2 Természetesen ennek a témának egy tágabb szempontú vizsgálatához hozzátartozna a változó használat kérdése is, hiszen a nyelv nem egy statikus rendszer (ld. fent), és a kifejezések kategóriaterjedelme is a változó használat függvénye, akárcsak a nyelvi tudás más aspektusai (Croft 2013: 102, 113; Langacker 1987: 57). Ennek a szempontnak a vizsgálata azonban túlmutat a jelen tanulmány keretein. 
Győri Gábor \& Hegedüs Irén:

A metonímia és a metafora mint a perspektivikus kategorizáció formái a lexikalizációban

és a grammatikalizációban

Argumentum 17 (2021), 275-293

Debreceni Egyetemi Kiadó

DOI: 10.34103/ARGUMENTUM/2021/15

amely a szó megalkotásának konceptualizációs alapjául szolgált (pl. a toll szó 'íróeszköz' értelemben). A szemantikai áttetszőség azonban relatív fogalom, és emiatt nem tehetünk kategorikus különbséget szószerinti és metaforikus, illetve metonimikus jelentésü nyelvi elemek között, hiszen ez utóbbiak esetében gyakran különböző mértékủ konvencionalizálódást is megfigyelhetünk. Ez a konvencionalizálódás elérheti azt a mértéket, mikor az adott elem a beszélők mentális lexikonjában már nem átvitt értelmüként jelenik meg, és ezért szószerinti jelentésűnek tekinthető. Így a szemantikai áttetszőség és a szószerintiség relativitásán keresztül eljutunk a nyelvi elemek etimológiájáig, amely a perspektivizációnak egy újabb fontos megnyilvánulása. A nyelvi elemek etimológiájának a vizsgálata egyrészt a történeti lexikalizációs folyamatokban megfigyelhető metaforikus és metonimikus kategorizációban és konceptualizációban megjelenő perspektívák miatt fontos, másrészt az etimológiák sok esetben magyarázattal szolgálhatnak azokra a nyelvek közötti eltérésekre, amelyek a világ kategoriális felosztásában találhatók. Az alábbiakban a perspektivizációnak ezt a háromféle megnyilvánulását fogjuk áttekinteni különböző példákon keresztül mind a lexikalizációban, mind a grammatikalizációban.

\section{A perspektivikus kategorizáció jelentősége és mechanizmusa}

Ahogy a Bevezetésből kitűnik, a nyelvben található kategorizációs perspektíváknak funkcionális jelentősége van. Ez a funkció a valóságnak az adott környezettel való hatékony interakció szempontjából való ábrázolása, ami nem lehet a világnak az emberi megismerés mechanizmusaitól független objektív tükrözése. Ennek az ábrázolásnak egyrészt igazodnia kell a specifikusan emberi környezet sajátosságaihoz, és azon belül a különböző szociokulturális jellegzetességeihez; másrészt gyakran módosulnia kell annak függvényében, hogy a környezetben folyamatosan változó körülményekhez és helyzetekhez való adaptáció milyen különböző interakciókat kíván meg. A perspektivikus látásmód, vagyis a környezet ilyenfajta kategorizációja, nem az emberi megismerés, és azon belül a nyelvi ábrázolás sajátja. Ahogy azt már említettük, a percepció már önmagában is perspektivikus jellegü. A megismerés már ezen a szinten sem objektívan képezi le a valóságot, mert a perspektivikus látásmód minden élőlény számára szükségszerü képesség a környezettel való hatékony interakció szempontjából. A nyelv az emberi társas megismerés szintjén valósítja meg a külvilág komplex értelmezését azzal összhangban, hogy az adott környezet, pontosabban annak jellemzői, az ember szociokulturális viselkedésében milyen szerepet játszanak.

A valóság perspektivikus ábrázolásának funkciója a nyelvben mint a társas megismerés eszközében különösen nagy jelentőséggel bír, hiszen az emberi környezet rendkívül bonyolult és összetett. A környezet ebben a kontextusban a valóság azon szegmensét jelenti, amelyet egy társadalmi csoport, vagyis ugyanazon nyelvi közösséghez tartozó egyének megtapasztalnak, és amellyel interakcióba lépnek. Ebben az értelemben a környezet rendkívül összetett, hiszen beletartoznak a szigorúan vett tárgyi környezet mellett maguk az egyének egyenként és csoportosan, a velük és közöttük zajló interakciók, valamint mindenfajta más interakció, amelyekben a nyelvi közösség egyedei egyénenként vagy közösen részt vesznek. Emiatt a valóság jelenségeivel kapcsolatos, és azokat a társas viselkedés szervezésének szempontjából megfelelő perspektívából ábrázoló tudattartalmak átadása még lényegesebb. Ennek lehetőségét és hatékonyságát a nyelvnek a társas megismerést szolgáló szimbolikus jellege, vagyis a mentális reprezentációkban összekapcsolt kognitív-kommunikatív funkciója biztosítja (Tomasello 2003: 48, 53). De a szimbolikus képesség is, a megismerés egyszerübb módozataihoz hasonlóan, az alapvető 
Györi Gábor \& Hegedüs Irén:

A metonímia és a metafora mint a perspektivikus kategorizáció formái a lexikalizációban

és a grammatikalizációban

Argumentum 17 (2021), 275-293

Debreceni Egyetemi Kiadó

DOI: 10.34103/ARGUMENTUM/2021/15

és általános kognitív képességeken alapul, mint például az analógia és az asszociáció, csak sokkal komplexebb formában. Tehát a nyelvi kategóriák a valóság megértésének olyan képzeleti struktúráin alapulnak, „mint sémák, metafora, metonímia és mentális képek” és „,közvetlenül nem feleltethetök meg semmi olyannak a valóságban, ami az emberi tapasztaláson kívül esik" (Johnson 1987: xi). Lakoff (1987: 8) szerint „az emberi kategorizáció lényegében egyszerre az emberi tapasztalás és képzelet kérdése”, mivel a valóság megtapasztalását a fent említett képzeleti struktúrák segítségével értelmezzük. Ezen képzeleti struktúrák szolgálnak a perspektivikus kategorizálás alapjául. A perspektívában voltaképpen az fejeződik ki, hogy milyen fizikális, illetve testi tapasztalás adja az alapját a valóság képzeleti megértésében megnyilvánuló testesültségnek, vagyis, hogy ez a testesültség konkrétan milyen tapasztalaton alapul (Johnson 1987: 36-37).

A perspektívák tehát alapjában véve a metaforikus és metonimikus konceptualizációkban nyílvánulnak meg. Így például az angol 'pohár' jelentésü glass szóban megtestesülő alapperspektíva az ÜVEGBÖL LÉVÖ (DOLOG) metonímiában jelenik meg, de ugyanez az alapperspektíva lelhető fel a magyar 'ilyen anyagból készült, kisebb-nagyobb méretü, hengeres, felül elkeskenyedő nyakban végződő, zárható edény; palack' jelentésü üveg szóban is (ld. MNyÉSz, üveg, 3. jelentés). Tehát ugyanaz a perspektíva akár kétfajta entitást is szemléltethet, illetve kijelölhet, ami teljes összhangban van Tomasello (1999: 9) azon megállapításával, miszerint a beszélők választásán múlik a világ értelmezéséhez alkalmazott perspektíva.

Felmerül azonban a kérdés, hogy az új perspektívák alkalmazása során, honnan és hogyan ismerjük fel, azaz értjük meg ezeket. Az új perspektíva felismerése és ezáltal az új referens azonosítása egy hagyományos kifejezés használatakor a nyelv kategorizáló funkcióján alapul, hiszen ,[a] nyelv az általánosságok, vagyis a kategóriák szempontjából müködik [...és...] bármely nyelvi kifejezés, bármilyen részletes legyen is, végső soron csak a referensek egy kategóriáját képviseli" (Croft \& Cruse 2004: 74). Mivel a nyelvi kifejezések kategorizálnak, egy kifejezésnek egy referensre vonatkozó használata mindig azt jelenti, hogy egy entitást egy már a tudatunkban létező kategóriába sorolunk. Ez nem különbözik akkor sem, amikor egy szemantikailag nem konvencionális kifejezést használunk a konverzációs implikatúrában (Traugott \& Dasher 2002: 38, 50).

Logikai szempontból ez természetesen egyfajta ellentmondást fog eredményezni az adott kifejezés által konvencionálisan reprezentált kategória és az implikatúrában használt új perspektíva által kijelölt új referens között. Azonban az új tapasztalatok értelmezése csak úgy tud müködni, hogy a Langacker (1987: 105) által „struktúraráhelyezés”-nek (imposition of structure) nevezett kognitív képességünk segítségével a megelőző tapasztalataink struktúráit ráhelyezzük az új tapasztalatainkra. Tehát a ,,[k]ategorizálás [...] a tapasztalatnak a már korábban létező struktúrák vonatkozásában történő értelmezése" (Langacker 2013: 17), vagyis bármilyen új tapasztalatot csak a tudatunkban már meglévő kategóriák alapján vagyunk képesek értelmezni. Ugyanakkor ezt a tapasztalatot nyelvileg is csak a már kialakult nyelvi kategóriáinkban meglévő tudás alapján tudjuk megfogalmazni, azaz csak valamilyen létező kifejezéssel tudjuk megnevezni (Blank 2003: 45). Ezt jól szemléltetik a fenti példák is, amelyekben a megnevezésben rejlő perspektíva alapján az angol 'pohár' értelemben vett glass szó az ÜVEGBŐL LÉVŐ DOLGOK kategória tagjaként jelöli a poharat, míg a magyar 'palack' jelentésü üveg szó az üveget helyezi az ÜVEGBŐL LÉVŐ DOLGOK kategóriába.

A fentiek eredményeképpen az új tapasztalat új kategorizáláshoz vezet azáltal, hogy az előhívott már meglévő ismereti struktúrákat átalakítjuk a konceptualizáló képességünk és a képzeleti struktúrák segítségével. Egy hagyományos kifejezés szemantikailag nem konvencionális 
Győri Gábor \& Hegedüs Irén:

A metonímia és a metafora mint a perspektivikus kategorizáció formái a lexikalizációban

és a grammatikalizációban

Argumentum 17 (2021), 275-293

Debreceni Egyetemi Kiadó

DOI: $10.34103 / A R G U M E N T U M / 2021 / 15$

használata az újszerủ kategorizáció céljából az esetek túlnyomó többségében a metonímia vagy a metafora kognitív mechanizmusán alapul, és ezt a kategorizáció prototipikus jellege teszi lehetővé (Geeraerts 1997: 112; Hampton 2006: 80). Geeraerts (1997: 110) ezt úgy magyarázza, hogy a prototípus lehetővé teszi, hogy könnyebben megértsük a használat számunkra újszerü, periférikus eseteit is. Az új kategoriák létrehozásának szempontjából ennek a mechanizmusnak az a lényege, hogy először egy adott entitást egy már létező kategóriába sorol, de a kategóriák prototipikus szerkezete következtében az csak egy nagyon periférikus tagja lesz a kategóriának. A periferikusság mértéke attól függ, hogy a kategória adott tagjának jellemzőit milyen valószínűséggel asszociáljuk a szóban forgó kategóriával vagy más kategóriákkal (Rosch 1978: 30). Ez a periferikusság tehát megengedi, hogy az adott entitást ugyanakkor úgy konceptualizáljuk, mint egy másik kategóriához tartozót, sőt, úgy is, mint egy új kategóriának a prototipikus középpontját, ezáltal egy új kategóriát létrehozva (Győri 2002: 144, 152). Ez utóbbi kognitív folyamat jelenik meg a metaforában és a metonímiában, és ezáltal alakul ki a glass, illetve az üveg szavak hasonló perspektíván alapuló poliszémiája. Ezt a folyamatot Seiler (1985: 117) nagyon találóan differenciáló integrációként írta le.

Ezek a mechanizmusok tehát eddigi ismereteket alkalmaznak, ami nem csak a mentális reprezentáció és a konceptualizáció szempontjából lényeges, hanem a konverzációs implikatúra szempontjából is kulcsfontosságú, hiszen a beszédpartner ismereteit is számításba kell venni. Ezáltal szolgálja a metafora és a metonímia a valóság értelmezését és megértését, mind a kognícióban, mind pedig a kommunikációban, vagyis a beszédpartnerek közötti kölcsönös megértést is az implikatúra során. Ennek következtében a beszélők által választható lehetséges perspektívákat kognitív és kommunikációs igények és célok befolyásolják, amelyeket Geeraerts (1997: 108) a történeti lexikai változást irányító két kommunikációs alapelvként, az expresszivitás és a hatékonyság elveként, fogalmazott meg.

Amikor Croft és Cruse (2004: 74) azt mondják, hogy bármilyen nyelvi kifejezésre érvényes az, hogy kategorizál, akkor ennek természetesen a nyelvben található funkcionális elemekre is vonatkoznia kell, vagyis ezek is kategorizálják a valóságot. Ezért mondja Dér (2019: 1.1.2.1), hogy a többek által dekategorizációnak nevezett grammatikalizációs folyamat esetében inkább kategóriaváltásról van szó, ,,mivel a keletkező egység nem kategória nélküli lesz, hanem eltérő kategóriájú". Az ilyen elemek, mint például a névelők, affixumok, prepozíciók, névutók stb. által kifejezett perspektívák a világgal kapcsolatos tapasztalatainkat nagymértékben sematizált és a dekontextualizáció következtében erősen általánosított kategoriákba helyezik (Langacker 2013: 241). Így például, amikor a határozott névelő a konkrét vagy absztrakt dolgok kate góriáinak meghatározottságát jelzi, akkor ezeket a dolgokat egy sokszorosan tágabb, nagyon általános és sematikus MEGHATÁROZOTT (DOLGOK) kategóriába helyezi. Ebbe a kategóriába a meghatározottság mint egyetlen közös jellemzö alapján tartoznak dolgok, vagyis az ,az X” kifejezés nagymértékben sematizált metonimikus jelentése 'meghatározottsággal jellemezhető X'.

Ugyanígy például a múlt idő grammatikai kifejezése egy cselekvés vagy folyamat múltban való megtörténtét fejezi ki, azaz az adott cselekvést vagy folyamatot a MÚLTBAN MEGTÖRTÉNT CSELEKVÉSEK / FOLYAMATOK kategóriába helyezi azáltal, hogy legfőbb jellemzője alapján metonimikusan '(egy) múltban megtörtént cselekvés vagy folyamat'-ként értelmezi egy általános és sematikus konceptualizáció formájában. Példaként említhető a grammatikai többes szám is, ugyanis Jackendoff (1991: 21) szerint, amit az azt jelölö grammatikai funkció kifejez, az „egy fogalmi függvény [...], amely argumentumát egy aggregátumba képezi le”. Más szóval az adott „dolgot” a SOKASÁGBA TARTOZÓ (DOLGOK) kategóriába helyezi az EGYSÉG/SOKASÁG (UNITY/MULTPLICITY) képi séma alapján (Croft \& Cruse 2004: 45, 64). Ezzel összhangban 
Györi Gábor \& Hegedüs Irén:

A metonímia és a metafora mint a perspektivikus kategorizáció formái a lexikalizációban

és a grammatikalizációban

Argumentum 17 (2021), 275-293

Debreceni Egyetemi Kiadó

DOI: 10.34103/ARGUMENTUM/2021/15

Langacker (1991: 76-78) úgy érvel, hogy a többes számú főnevek szemantikai szempontból voltaképpen megszámlálhatatlan főnevek, vagyis egy másik főnévosztályba tartoznak. Tehát, Jackendoff (1991: 21) terminológiáját használva, míg az argumentum, azaz a megszámlálható egyes számú fönév, konceptuálisan behatárolt, az általa jelölt dolgok aggregátuma konceptuálisan nem behatárolt lesz, mint amilyenek a megszámlálhatatlan főnevek is.

\section{Perspektívák a lexikalizációban}

A nyelvi kategóriák létrehozásának folyamatában működő perspektivikus látásmód mindig a már megszerzett és elraktározott ismereteken alapul. Ez már eleve kihatással van arra, hogy melyek azok a lehetséges perspektívák, amelyek közül választhatunk. Ha a lexikalizációt nézzük, akkor már maga az komoly befolyásoló tényező, hogy egy nyelv adott szókincse szolgáltatja ezeket az ismereteket, méghozzá olyan formában, amelyek már önmaguk is perspektivikus konceptualizációt jelenítenek meg a nyelvi jelentésen keresztül (Geeraerts 1997: 8). A lexikalizáció esetében ezek a már meglévő perspektivikus konceptualizációk képezik az alapját az újabb perspektivizációknak, mégpedig úgy, hogy az új nyelvi kategorizációkat az ezekben foglalt ismeretek metaforikus és metonimikus feldolgozásával hozzuk létre (Johnson 1987: xi; Lakoff 1987: 8).

A valóságról alkotott ismereteink alapja természetesen a tapasztalat megszerzésének biológiailag adott módozatai, azaz a környezetünkkel való interakcióhoz elengedhetetlen percepció, valamint a vele összefüggő motoros tevékenység, amelyek alapján aztán a megtestesült sémáink létrejönnek (Johnson 1987: 20). A nyelvi kategorizációban elsősorban a kategorizálás alapszintje az, amelyik szorosan a percepcióhoz és a motoros tevékenységhez kötődik, ahogy azt Rosch és munkatársainak (Rosch et al. 1976; Rosch 1978) vizsgálatai ki is mutatták. Azonban már az alapszintü kategóriák esetében is könnyü példákat találni a különböző lehetséges perspektívákra a kategóriaterjedelmek nyelvek közötti összevetésében (Győri 2017). De különbözőségük ellenére ezen perspektívák mindegyike funkcionális szempontból tökéletesen képes müködni. Például a magyar pohár szónak a kategóriaterjedelme nem egyezik meg sem a német Glas, sem az angol glass szavak ilyen terjedelmével, vagyis ezek jelentése nem egyezik meg egyértelmúen a pohár szó jelentésével. A pohár szó extenziója nemcsak a német Glas szó extenzióját fedi le, hanem átfedésben van a német Becher szó extenziójával is, ugyanis ez a nem üvegből készült poharakra (pl. papír- vagy múagyagpohárra) használt német kifejezés. Továbbá a magyar pohár szó ebből a szempontból részleges átfedésben van az angol cup szóval, mivel a papír- vagy mủagyagpoharakra használt angol kifejezés a paper illetve plastic cup. A Glas és glass szavak szűkebb kategóriaterjedelme nyilvánvalóan a szemantikai áttetszőségükböl (azaz metonimikus jellegükböl) adódó szemantikai blokkolás következménye. Ebből az is kitünik, hogy a magyar csésze szó kategóriaterjedelem szempontjából csak részleges átfedésben van az angol cup szóval. Ugyanakkor a német Becher szó, míg részleges átfedésben van a magyar pohár szóval, az angol cup szóval is csak részleges átfedésben van, de a kategóriaterjedelem (vagy extenzió) más részére vonatkozólag. Az angol cup azon terjedelmét, amelybe a paper és plastic cup nem tartoznak bele, valamint a magyar csésze szó terjedelmét, egy harmadik német szó, a Tasse fedi le (lásd 1. ábra). 
Györi Gábor \& Hegedüs Irén:

A metonímia és a metafora mint a perspektivikus kategorizáció formái a lexikalizációban

és a grammatikalizációban

Argumentum 17 (2021), 275-293

Debreceni Egyetemi Kiadó

DOI: 10.34103/ARGUMENTUM/2021/15

\begin{tabular}{|c|c|c|c|}
\hline & magyar & német & angol \\
\hline & csésze & Tasse & \multirow{2}{*}{ cup } \\
\hline & \multirow{2}{*}{ pohár } & Becher & \\
\hline $\mathrm{ra}$ & & Glas & glass \\
\hline
\end{tabular}

1. ábra. Az eltérö kategóriaterjedelmekben megnyilvánuló különbözö perspektívák

Ez a teljesen hétköznapi példa jól szemlélteti, hogy az objektív valóság kategorikus felosztása több perspektíva alapján is előfordulhat, és ezért nyelvenként eltérő lehet, de a különböző kategorizálások a nyelv kognitív-kommunikatív szerepe szempontjából egyaránt funkcionálisak és adaptívak lehetnek. Ez jól mutatja, „,hogy a kategorizáció nem csak a kogníciótól függ, hanem a kultúra is alapvetően befolyásolja, megteremtve ezáltal az alternatív kategorizációk kialakulásának lehetőségét" (Kövecses \& Benczes 2010: 49).

Egy kifejezés szemantikai áttetszősége sok esetben önmagában is, nyelvek közötti összevetés nélkül, képes árulkodni arról a perspektíváról, amely a kategorizáció alapjául szolgál, ahogy azt a fent tárgyalt Glas, glass és üveg szavak esetében is láthattuk. Ezt gyakran még komplexebb formában figyelhetjük meg derivált lexémák esetében a bennük lévő tő szemantikai áttetszősége folytán, amely természetesen különböző mértékű lehet (Kövecses 2017: 122). Kövecses (2017) a magyar es- tő esetében vizsgálta meg, hogy a derivációs elemek milyen metaforikus és metonimikus konceptualizációkat eredményeznek, valamint többek között azt is, hogy az áttetszőség mennyiben befolyásolja egy nyelv fogalmi szerveződését a szó- és jelentésalkotás folyamatában. Ez a fogalmi szerveződés valójában a lexikalizációt kísérő konceptualizációkban megjelenő perspektívákból adódik.

Vegyük példának a függöny szót, amelyben a szótő áttetszö, és a derivált alak szemantikája a kategorizációs perspektíva metonimikus jellegéröl árulkodik ('az, ami függ'), vagyis a derivációs elem perspektivikusan a FÜGGÖ DOLGOK kategóriába helyezi az így megnevezett objektumokat. De a szemantikai áttetszőség különböző mértékü lehet, mint például a padlás szó esetében, ahol a szó morfológiai szerkezete nem teljesen áttetsző, és így a benne található elemek tartalmi és funkcionális jelentése sem. A szó úgy lexikalizálódott, hogy a pad szóhoz járult az -ol igeképző, létrehozva a 'kideszkáz' jelentést, majd a padol alakhoz járult az -ás főnévképző, létrehozva a padlás szót, amely metonimikusan a padolás (azaz kideszkázás) által létrehozott helyet, illetve építészeti szerkezetet jelenti (ld. TESz, padlás). Itt a tő jelentésének elhomályosultsága mellett a szóban rejlő -(o)l- képző is elhomályosult, mind morfológiailag, mind funkcionális jelentését tekintve. Ez a példa a szószerinti jelentés fogalmának relatív jellegét is jól mutatja. Szószerinti jelentésről csak a beszélők nyelvi kompetenciájának függvényében beszélhetünk abban az értelemben, hogy a beszélőknek az adott lexémához kapcsolódó konceptualizációját mennyire 
Győri Gábor \& Hegedüs Irén:

A metonímia és a metafora mint a perspektivikus kategorizáció formái a lexikalizációban

és a grammatikalizációban

Argumentum 17 (2021), 275-293

Debreceni Egyetemi Kiadó

DOI: 10.34103/ARGUMENTUM/2021/15

befolyásolja, vagy egyáltalán befolyásolja-e valamilyen morfológiai és szemantikai áttetszőség, akár tudatosult, akár nem tudatosult formában (vö. Kövecses 2020: 25).

Ahogy az előzőkből kitűnik, a perspektíva megmutatkozik egyrészt a fennálló kategorizációban, vagyis a világnak a nyelv általi felosztásában a nyelvi kategóriák alapján, másrészt a szemantikailag áttetsző kifejezések metaforikus és metonimikus jellegében, legyen az szóképzés vagy szóösszetétel, illetve a kifejezések metaforikus és metonimikus kiterjesztéseiben. Ez utóbbiakkal kapcsolatban egy érdekes jelenség, hogy egy konceptuális metafora forrás- és céltartománya közötti megfelelések is eredményezhetnek lexikalizációt. Ez azt jelenti, hogy a forrástartományhoz tartozó kifejezések között lehet olyan, amely az adott konceptuális metafora Lakoff(1990: 48) által leírt ontológiai és episztemológiai egyezések hatására nyer új önálló jelentést. Erre jó példát nyújtanak a Kövecses (2000: 21) és a Kövecses és Benczes (2010: 86, 97) által részletesen vizsgált és leírt A DÜH EGY TARTÁLYBAN LÉVÖ FORRÓ FOLYADÉK és A DÜHÖS EMBER EGY NYOMÁS ALATT LÉVÖ FORRÓ TARTÁLY fogalmi metaforák. Az itt említett lexikalizációkhoz nagyban hozzájárulhatott ezeknek a fogalmi metaforáknak a Kövecses (2005: 39-40) által leírt univerzális jellege is, amely egy kulturálisan széles körben elterjedt perspektívát jelez. A magyar nyelv értelmezö szótára szerint a forr ige 4. jelentése '(erős érzelmi indulat) kitörni készülö hevességgel gyötör, emészt vkit', míg a robban ige 2. jelentése 'robban vki: érzelmi v. indulati feszültsége kitör belőle'. Az angolban ezzel a két igével kapcsolatban hasonló meghatározásokat találunk: a The American Heritage Dictionary szerint a boil ige 3. jelentése 'felkavart vagy nagyon izgatott, különösen düh következtében', míg az explode ige 4. jelentése 'érzelmileg kitörni'. Ugyanezt találjuk a német nyelvben: A Duden Online szerint a kochen ige 6. jelentése 'belsőleg nagyon izgatott, dühös', 'dühtől, haragtól forr', míg az explodieren ige 2. jelentése 'hirtelen érzelmi kitörést mutat', 'dühtől, haragtól felrobban').

A morfológiailag és szemantikailag áttetsző kifejezésekben tetten érhető az amúgy egymástól elválaszthatatlan és párhuzamoson zajló kategorizációs és lexikalizációs folyamat. Azonban a szemantikailag egyáltalán nem áttetsző, vagyis az elméletileg szószerinti jelentéssel bíró, kifejezések sem készen kapottak. Valamilyen módon ezen kifejezések szemantikájának is ki kellett alakulniuk. Ezekben az esetekben nagyobb mértékű elhomályosultságról van szó, amelynek hátterében történeti lexikalizációs folyamatok állnak. Az ilyen folyamatok eredete is a beszélők szinkrón nyelvi aktivitásában létrehozott szemantikai újításokban keresendő, amelyek föleg metaforán és metonímián alapulnak (Nerlich \& Clarke 1992: 137). Traugott (2011a) szerint a beszélők által konverzációs implikatúra formájában létrehozott, a hallgatót inferálásra ösztönző, ilyen jelentésmódosítások állnak a szemantikai változások hátterében. Tehát az eredetileg szemantikailag áttetsző metonimikus és metaforikus jelentésekből konvencionálódás útján szószerinti jelentések alakultak ki, amely folyamatot általában az azt kísérő fonetikai változás is támogat. Ezért mondja Campbell (1998: 267), hogy a történeti jelentésváltozás és lexikalizáció is az „emberi gondolkodás asszociatív mintáin” alapul. Ahogy a bevezetőben említettük, a környezet nem egy statikus rendszer, állandó mozgásban és változásban van, és a nyelvnek ehhez folyamatosan igazodnia kell. Ezért a beszélők szinkrón nyelvi tevékenysége során megjelenő új kifejezések a környezettel (a valóság egy adott szegmensével) való interakció által kognitívan motivált perspektívákat tükröznek. Ha egy új kifejezés, vagyis perspektivikus kategorizáció, kontextuálisan funkcionálisnak (azaz a kommunikatív interakcióban hatékonynak és informatívnak) bizonyul, akkor az új kifejezés nagy valószínüséggel konvencionalizálódni fog a beszédközösség nyelvhasználatában (Blank 1999: 63; Geeraerts 1997: 105; Regier, Kemp, \& Kay 2015: 237; Traugott \& Dasher 2002: 34). Az új kategorizálás eredményeként egy új kollektív 
Győri Gábor \& Hegedüs Irén:

A metonímia és a metafora mint a perspektivikus kategorizáció formái a lexikalizációban

és a grammatikalizációban

Argumentum 17 (2021), 275-293

Debreceni Egyetemi Kiadó

DOI: 10.34103/ARGUMENTUM/2021/15

konceptualizáció alakul ki, amely magában foglalja a megértés közös perspektíváit, és egy új, adaptív kulturális kategóriaként fog müködni a közösség társas megismerésében.

A fentebb említett angol glass és német Glas 'pohár' jelentésü szavak, valamint a magyar üveg szó, 'ilyen anyagból készült, kisebb-nagyobb méretü, hengeres, felül elkeskenyedő nyakban végződő, zárható edény’ jelentéssel, jó példát szolgáltattak arra, amikor ugyanazon perspektivikus kategorizáció különböző konceptualizációk, illetve lexikalizációs folyamatok alapjául szolgálhat. Bár a fenti esetekben már inkább szószerinti jelentésekről beszélhetünk, a szóban forgó szóalakok esetében mégsem mondhatjuk, hogy szemantikailag nem áttetszők. Szemantikailag teljesen elhomályosult alakoknál, ahol látszólag semmilyen jelentésbeli érintkezés nincs, csak az etimológiai adatok tanúskodhatnak két (vagy több) alak közös eredetéről, és ezáltal egy esetleges hasonló konceptualizációról. Egy ilyen esetet képeznek például az angol chin 'áll(kapocs)' és knee 'térd(kalács)' szavak, melyeknek az ösindoeurópai rekonstruált formái * $\hat{g} e n u-$, illetve * $\hat{g} o ́ n u-$. Azonban Mallory és Adams (1997: 336) úgy gondolják, hogy a két testrész formája alapján valószínủsíthető, hogy a két szó ugyanabból a jelentésből ered, és alakilag valójában egy tő két ablautfokáról van szó. Ezt támasztja alá az a magyarázat, mely szerint mindkét testrész lexikalizációja a HAJLAT/GÖRBÜLET (BEND/CURVE) képi sémán alapuló metonimikus konceptualizációra vezethető vissza (Győri \& Hegedűs 2012).

A Johnson (1987: xi) és Lakoff (1987: 8) által leírt, a világ megértéséhez alkalmazott képzeleti struktúrák következtében ennek természetesen a fordítottja is lehetséges, vagyis amikor ugyanaz a jelenség különböző perspektívákból történő kategorizálás alapján lexikalizálódik. Ez általában különböző nyelvek összehasonlítása során figyelhető meg. Erre nagyon jó példát szolgáltatnak az egyformán 'felhö' jelentésü angol cloud, a német Wolke és a norvég sky szavak történeti lexikalizációs folyamatai. Az angol cloud szó az ösindoeurópai *glūto- 'felhalmozott tömeg, gomolyag' tőből származtatható (ld. OED Online, cloud), a német Wolke szó az ősgermán *welkaz 'nedves' tőből ered (Orel 2003: 453; Mallory \& Adams 1997: 639), míg a norvég sky az ősindoeurópai * $(s) k e u\left(h_{x}\right) o$ - 'takarás' szótőre vezethető vissza (Mallory és Adams 1997: 134). Az angol sky 'égbolt' szó szintén ebből a tőből származik, de nem egyenes ágon, hanem kölcsönzés formájában. Az óangol még 'felhő' jelentéssel vette át a scēo szót a korai skandinávból, melynek jelentése a középangol korszakra változott meg (ld. OED Online, sky). A változás iránya azt a metonimikus konceptualizációt sugallja, hogy 'az a hely, ahol a felhők vannak', valamint szemlélteti a már lexikalizálódott konceptualizációk befolyását a további lexikalizációkban megjelenő perspektívákra (ld. fent).

Ezek a példák jól illusztrálják a tapasztalat és a képzelet összjátékát a kategorizációban (ld. Lakoff 1987: 8). Ennek az összjátéknak a következménye, hogy a felhővel mint természeti jelenséggel kapcsolatos különböző tapasztalatokon (a gomolyagforma, a nedvesség és a takarás) alapuló metonimikus perspektívák (gomolyagformájú valami, nedves valami, takaró valami) olyan alternatív konceptualizációkhoz vezetnek, amelyek végül ugyanazt a kategóriát eredményezik (ld. Kövecses \& Benczes 2010: 145; Langacker 1987: 111).

\section{$4 \quad$ Perspektívák a grammatikalizációban}

A lexikalizáció kifejezés egyaránt használatos a szinkrón nyelvi aktivitás során történő újszerü szóalkotásra és szóhasználatra, valamint a lexikai elemek történeti megjelenésének folyamatára. Ez azért sem véletlen, mert a szinkrón folyamatok adják a történeti változások alapját, 
Győri Gábor \& Hegedüs Irén:

A metonímia és a metafora mint a perspektivikus kategorizáció formái a lexikalizációban

és a grammatikalizációban

Argumentum 17 (2021), 275-293

Debreceni Egyetemi Kiadó

DOI: 10.34103/ARGUMENTUM/2021/15

vagyis ez utóbbi az előző egyenes következménye. Ezzel szemben, a grammatikalizáció fogalma csak a grammatikai elemek történeti megjelenését jelenti, de ahogy a történeti lexikalizációs folyamatok során végbement változások a szinkrón nyelvhasználatból vezethetők le, úgy a grammatikai elemek eredete is a szinkrón nyelvhasználatban keresendö. Ezen elemek szintén olyan kifejezésekből származó konvencionálódott alakok, amelyek konverzációs implikatúra formájában újszerü konceptualizációkat közvetítettek metafora vagy metonímia formájában, azonban a nagymértékü konvencionalizálódás során eredetileg tartalmi szavakból funkcionális elemek váltak (Brinton \& Traugott 2005: 42-43; Harder \& Boye 2011: 65; Traugott 2011b: 26; Traugott \& Dasher 2002: 5). Heine és Kuteva (2004: 3) szerint ezért „,a grammatikalizáció [...] mindenekelött egy szemantikai folyamat", vagyis a grammatikai elemek és szerkezetek megjelenése egy nyelvben szintén szemantikai változások eredménye.

A fentieket jól szemléltetik a következő példák. A magyar -ba/-be helyhatározói rag a belé névutó grammatikalizációjával alakult ki; ez a névutó a bél fónév toldalékos alakja (Bárczi, Benkő \& Berrár 1967: 323). Ebben a példában jól látszik az a Johnson $(1987: 29,41)$ által leírt folyamat, amely során a testi tapasztalásokban visszatérő mintázatok következtében kialakul egy képi séma, jelen esetben a TARTÁLY séma. Nyelvi szinten a -ba/-be példában azt látjuk, hogy a TARTÁLY sémát megtestesítő egyik konkrét tapasztalat lexikalizálódott formája adja a forrásstruktúrát a grammatikalizációs folyamat megindulásához. A grammatikalizáció alapja az a metonimikus konceptualizáció, hogy 'olyan térbeli viszonyban áll a környezetével, mint a bél a testtel', amely aztán a képi sémának megfelelően a valóság sokkal több esetére érvényes sematikusan, mint az a tapasztalati forrástartomány, amelyből származik. Johnson (1987: 126) listájában megtalálható a FELÜLET képi séma is, amellyel hasonlóképpen magyarázható a -ral-re térbeli viszonyt, a mozgás irányultságát kifejező szuffixum kialakulása az ugor *raクз 'felület, felszín' fönévből (ld. Uralonet, № 1836). Itt a grammatikalizáció valószínüleg egy olyan metonimikus konceptualizációra vezethető vissza a FELÜLET séma egyik velejárója, illetve implikációja (entailment) alapján (ld. Johnson 1987: 22), miszerint 'olyan tulajdonsággal rendelkezik, hogy egy tárgy horizontálisan (pl. asztal $r a$ ) vagy vertikálisan (pl. fal $r a$ ) ráhelyezhetö úgy, hogy az nem mozdul el'.

Tehát a grammatikalizáció is egy kulturális kategorizációs mechanizmuson alapuló, perspektívákat tükröző történeti folyamat. Azonban amikor a tartalmi szavak a nyelvi változás során grammatikai elemekké alakulnak fonetikai erózió és szintaktikai reanalizáció kíséretében, a szemantikai változás típusa eltér a lexikalizációs folyamatokétól, mivel az a szemantikai tartalom megfakulásával jár együtt (Wischer 2000: 364). A szemantikai tartalom megfakulásának a grammatikalizációs jellegü szemantikai változás során lényeges szerepe van. A szemantikai összetettség gyengülése a grammatikalizálódás következtében egy olyan jelentést hoz létre, amely sok különböző tapasztalatra átfogóan érvényes, és azokra széles körben alkalmazható perspektívát fejez ki. Mivel minden grammatikai elem jelentéssel bír (Langacker 2011: 79), a szemantikai funkciójuk pont egy ilyen általános perspektíva nyelvileg gazdaságos és hatékony módon történő kifejezése. Harder és Boye (2011: 65) szerint a grammatikalizációból „eredő kombináció (azaz konstrukció) 'funkcionálisan erőteljesebb', mint amilyen a 'gazda'-kifejezés önmagában lenne", annak ellenére, hogy a fogalmi tartalom megfakult.

Ez a funkcionalitás felé történő elmozdulás a grammatikalizálódás során magában foglalja a fogalmi tartalom sematizálódását (Langacker 2011: 82), ugyanis a kifejezések a sematikusság vagy a specifikusság paramétere mentén változhatnak abban a tekintetben, hogy ez a tartalom milyen pontosságú és részletességü (Langacker 2013: 19). Tehát a sematizálódás az absztrakció szintjének növelését jelenti, és a tapasztalatok sokféleségétől valamint az ezekben fellelhető 
Győri Gábor \& Hegedüs Irén:

A metonímia és a metafora mint a perspektivikus kategorizáció formái a lexikalizációban

és a grammatikalizációban

Argumentum 17 (2021), 275-293

Debreceni Egyetemi Kiadó

DOI: 10.34103/ARGUMENTUM/2021/15

közös jegyektől függően olyan mértéket érhet el, hogy az adott nyelvi elemek funkcionalitása kerül elötérbe a fogalmi tartalmukkal szemben (Langacker 2013: 17; Tolcsvai Nagy 2013: 247248). De mivel minden nyelvi kifejezés kategorizál (Croft \& Cruse 2004: 74), a grammatikalizáció esetében a sematizálódás szélesebb kategoriális belefoglaltságot eredményez a konkrétabbtól az absztraktabb felé történő szemantikai eltolódás következtében. Ennek egy szükségszerü velejárója a dekontextualizáció az eredeti jelentés nagyszámú részletének kizárása által (Langacker 2013: 241). Heine, Claudi és Hünnemeyer (1991: 39) ezt úgy fogalmazzák meg, hogy a grammatikalizáció a szóban forgó fogalom (azaz forrásstruktúra) intenzionális tartalmának csökkenését és extenziójának növekedését vonja maga után, ami aztán a célstruktúra intenzióját és extenzióját meghatározza.

Tehát a grammatikalizáció is egy kategorizációs folyamat, amelynek valamilyen konceptualizációs mechanizmuson kell alapulnia. A funkcionális elemeknek a kategorizáló tulajdonsága esetében is ez a mechanizmus felelős azért, hogy egy jelenséget hogyan értelmezünk, illetve milyen alapon helyezzük azt a grammatikalizációs folyamat elején egy már meglévő kategóriába, amelyből aztán egy új kategória kiválik és differenciálódik. A kategorizálás alapja csak a szokásos analógia és asszociáció lehet, vagyis a metaforizáció és metonimizáció. Azonban a grammatikalizáció felé történő szemantikai és egyben funkcionális elmozdulást motiváló és indukáló konceptualizációk eltérnek a lexikalizációs folyamatokban megfigyelhetőktől. Bár a szemantikai változás a grammatikalizációban is a metafora és a metonímia mechanizmusain alapul a forráskifejezés tartalmi oldalának gyengülése ellenére, Brinton és Traugott (2005: 107) szerint a metaforizáció, és különösen a metonimizáció, a lexikalizációban inkább az enciklopédikus ismeretekre, a grammatikalizációban pedig inkább a nyelvi jelentésre támaszkodik.

Mivel a grammatikai elemek is kategorizálnak, az ő esetükben is beszélhetünk a világ kategoriális felosztásának a kérdéséről. Akárcsak a lexikális elemeknél, ez a kategorizálás is valamilyen perspektívát tükröz, amelynek alapján értelmezzük és konceptualizáljuk a valóságot. Ez a perspektivikusság akkor válik igazán szembetűnővé, amikor bizonyos grammatikai elemek eltérő funkcionális használatát figyelhetjük meg különböző nyelveket, de akár egy nyelv különböző változatait összehasonlítva. A valóságnak ez a perspektivikus értelmezése gyakran már a konkrét térbeli viszonyok konceptualizációjában megmutatkozik, vagyis az objektív értelemben vett ugyanolyan térbeli viszonyok nyelvi kifejezésében látszik, hogy az emberi elme még ezeket is képes különböző módon értelmezni, vagyis alternatív módon konceptualizálni.

Például az angolban és a magyarban is ugyanolyan térbeli viszonyként értelmezzük azt a helyzetet, amikor valamilyen tárgy egy asztal síkjával érintkezve nem mozdul el a föld irányába a gravitáció hatására, valamint azt a helyzetet, amikor egy tárgy egy fal síkjával érintkezik ugyanúgy nem elmozdulva a föld felé (vö. Tolcsvai Nagy 2013: 71, 247-248). Tehát ebben az esetben sem az angol, sem a magyar nem tesz különbséget nyelvileg az amúgy objektív fizikai értelemben véve egymástól eltérő (vertikális és horizontális) térbeli viszony között, és mindkettőt az on elöljárószóval, illetve az -on/-en/-ön szuffixummal jelöli. Ez mind a két térbeli viszony esetében ugyanazt a perspektívát feltételezi, mely perspektíva egy közös sematikus konceptualizációt eredményez mindkét viszonyra vonatkozóan. Ez a konceptualizáció a két objektum közötti térbeli viszonyt mindkét esetben azoknak egy közös jellemzője alapján értelmezi metonimikusan, ami olyasféleképpen írható le, hogy 'felülettel elmozdulás nélküli szoros érintkezés'. Ezzel szemben a német nyelv különbözőképpen konceptualizálja a két viszonyt. A vertikális érintkezést az auf elöljáróval fejezi ki, amely elsősorban az -on/-en/-ön szuffixumnak felel meg, pl. auf dem Tisch ('az asztalon'), a fenti típusú horizontális érintkezést pedig az an 
Györi Gábor \& Hegedüs Irén:

A metonímia és a metafora mint a perspektivikus kategorizáció formái a lexikalizációban

és a grammatikalizációban

Argumentum 17 (2021), 275-293

Debreceni Egyetemi Kiadó

DOI: 10.34103/ARGUMENTUM/2021/15

elöljáróval, amely főként a -nál/-nél szuffixum ekvivalensének tekinthető (térbeli értelemben), pl. an der Wand ('a falon').

A fent említett vagy más térbeli viszonyt kifejező grammatikai elemek egyéb alkalmazásait nyelvek közötti összehasonlításban vizsgálva sok hasonló példát találunk az ilyen viszonyok alternatív konceptualizációjára. Különösen igaz ez, ha ezeknek a viszonyoknak a különböző objektumokkal való összefüggéseit is figyelembe vesszük, ahogy ez a fenti példára is érvényes. Ennek legfőbb oka az, hogy valójában a grammatikai elemek is rendelkeznek a poliszémia tulajdonságával, és ez az, ami ebben a jelenségben megnyilvánul. Tolcsvai Nagy (2013: 248) ezt úgy fogalmazza meg, hogy ,„[a] grammatikai elemek poliszém hálózatát az őket kidolgozó lexikai elemekkel közösen kialakított gyakori, konvencionalizálódott viszonyokban lehet leírni”. Ezt figyelhetjük meg a fent említett német an elöljáró esetében, amikor például az an dem Tisch kifejezésben az an nem azt jelenti, hogy 'felülettel elmozdulás nélküli szoros érintkezés', hanem két objektum egymásmellettiségét fejezi ki. Az alternatív konceptualizációt nagyon jól illusztrálja a brit és amerikai angol közötti eltérés is 'az utcán' jelentésü kifejezés estében. A brit angolban többnyire az in the street kifejezés használatos, és a benne szereplő in elöljáró AZ UTCA EGY TARTÁLY metaforikus konceptualizációról tanúskodik. Ezzel szemben az amerikai angolban ugyanolyan értelemben használatos on the street kifejezésben AZ UTCA EGY FELÜLET metaforikus konceptualizáció jelenik meg.

A fenti példákban olyan értelemben van szó alternatív konceptualizációkról, hogy az adott grammatikai elemek bizonyos lexikai elemekkel való konvencionalizálódott használatában valamilyen viszony vagy helyzet perspektivikus értelmezése nyilvánul meg (ld. Tolcsvai Nagy 2013: 248). Ezért itt is a világnak a nyelv általi felosztásáról van szó, vagyis arról, hogy egy grammatikai elemnek egy lexikai elemmel való konvencionalizálódott használatától függően például az utca vagy egy tartály vagy egy felszín, illetve egy tárgynak az asztallal való vertikális vagy a fallal való horizontális térbeli kapcsolata ugyanabba a térviszony-kategóriába esik vagy két különbözőbe. De az alternatív konceptualizáció megnyilvánulhat magában a grammatikalizációs folyamatban is, vagyis abban, hogy milyen forrásfogalmakból alakulnak ki a különböző grammatikai kategóriák. Heine, Claudi és Hünnemeyer (1991: 38) állítása szerint egy forrásfogalomból akár több grammatikai kategória is származhat, és fordítva, egy grammatikai kategóriának több forrásfogalom is képezheti az eredetét. Heine és Kuteva (2004) World Lexicon of Grammaticalization címü könyvükben összegyüjtöttek számos olyan általános, átfogó fogalmi kategóriát, amelyek a világ nyelveiben forrásai lehetnek egy adott grammatikai kategóriának, és rendszerezték, hogy egy-egy fogalmi kategóriából milyen különböző grammatikai kategóriák származhattak.

Mivel a grammatikalizáció esetében egy történeti folyamatról van szó, a szemantikai áttetszőség a grammatikai elemek vonatkozásában viszonylag ritka jelenség, és így a funkcionális elemek kialakulásának hátterében meghúzódó perspektivikus konceptualizációról többnyire már csak azok etimológiai elemzése árulkodhat. De például a grammatikai jövő idő képzése nyelvek közötti összehasonlításban jó illusztrációja annak, hogy a szemantikai áttetszőség relatív volta a grammatikai elemekben is megmutatkozik (Tolcsvai Nagy 2013: 185). Ugyanakkor az alternatív konceptualizációnak azt az esetét is jól illusztrálja, amikor ugyanaz a grammatikai kategória több különböző forrásfogalomból is kialakulhat.

Az erős szemantikai áttetszőségének köszönhetően a jövő idő kifejezésére használt angol going to segédige grammatikalizálódásának folyamatát nagyon sokan elemezték. E folyamat során a going to igei kifejezés tartalmi jelentéséböl, 'menni valahová', alakult ki az eredeti jelentésből adódó implikációkra szűkült funkcionális jelentés. Ezek az implikációk nem a 
Györi Gábor \& Hegedüs Irén:

A metonímia és a metafora mint a perspektivikus kategorizáció formái a lexikalizációban

és a grammatikalizációban

Argumentum 17 (2021), 275-293

Debreceni Egyetemi Kiadó

DOI: $10.34103 / A R G U M E N T U M / 2021 / 15$

társalgási implikatúráknak felelnek meg, mert itt, és általában a grammatikalizációban, ahogy azt Nagy C. Katalin (2018: 98) mondja, többnyire olyan pragmatikai következtetések játszanak szerepet, amelyek nem feltétlenül a beszélö szándékát tükrözik. Tehát jelen esetben ezen implikációk (azaz pragmatikai következtetések) közé tartozik, hogy ha valaki megy valahová, azt valamilyen céllal teszi, mely cél a jövőben fog bekövetkezni. Így a két esemény közötti asszociáción alapul a szándékolt jövőbeni cselekvés, valamint az ennek alapján megjósolt valamilyen jövőbeni történés metonimikus konceptualizálása. Az angol will segédige szintén a jövő idő kifejezésére szolgál, és az ősgermán *weljan- 'akarni' (Kroonen 2013: 578) igéből grammatikalizálódott. Mivel az akarat vagy a szándék többnyire implikálják a jövőben történő cselekvést, a will segédigében a jövő időnek az akarat vagy szándék perspektívájából való értelmezése jelenik meg, és így ez a cselekvés mint az akarattal vagy a szándékkal asszociált következmény konceptualizálódik metonimikus formában.

A grammatikai jövő idő egy harmadik perspektívából történő konceptualizációja nyilvánul meg a svéd skall segédigében, amely az ösgermán *skulan- 'köteles (valamit tenni)' (Kroonen 2013: 450) igéből grammatikalizálódott. ${ }^{3}$ Itt nem a majdani cselekvést végrehajtó személy saját szándéka implikálja a cselekvés jövőidejüségét, hanem egy másik személy szándéka a cselekvést végrehajtószemélyre vonatkozóan váltja ki a jövő idejü cselekvésre történő asszociációt, és ennek folytán a metonimikus konceptualizációt. Továbbá, a németben a grammatikai jövő időt a werden segédigével képzik, amely úgy grammatikalizálódott, hogy a werden 'válni valamivé' jelentést hordozó főigéből alakult ki, amely az ősgermán *werpan- '(meg)történik, válik valamivé' igéből származik (Kroonen 2013: 581). Ez utóbbi az ősindoeurópai *wer- 'fordul, hajlik' igetőre vezethető vissza, mely igének tartalmi jelentéséből metaforikusan alakult ki a későbbi ősgermán ige jelentése, miszerint A VÁLTOZÁS FORDULÁS. De a werden segédige későbbi grammatikalizációjában történő funkcionális jelentésváltozás metonimikus jelleggel mehetett végbe a változásnak a jövőben előálló állapottal vagy cselekvéssel való asszociációja alapján.

A jövő idő egy ötödik féle konceptualizációja a magyar fog segédigében fedezhető fel, amely a fog föigéből grammatikalizálódott, mely utóbbi az ugyanilyen jelentésű ősi ugor *риүз- 'fog, megfog' igetőre vezethető vissza (Uralonet, № 1830). Bárczi, Benkő és Berrár (1967: 421) szerint grammatikalizációja viszonylag késői jelenség a magyarban, és magyarázatuk alapján például ,[a]z írni fog eredetileg csak a cselekvéshez való hozzáfogást fejezte ki, bármely időben; de éppen kezdő értelménél fogva a beálló cselekvés: a jövő idő jelölője lett". Grammatikalizációja azon a perspektíván alapul, hogy a jövő időt egy cselekvés alapján feltételezett szándék felől értelmezzük, azaz, ha valaki megfog, kezébe vesz valamit, akkor az azt implikálja, hogy azzal valamilyen terve van, készül valamire. Már a 'hozzáfog' kifejezés jelentése is ezen az implikáción alapul. Tehát egy konkrét cselekvéssel valamilyen későbbi cselekvést asszociálunk, és ez adja az alapját a jövő idő metonimikus konceptualizációjának.

Ha egy grammatikai kategória kialakulhat különböző konceptualizációs útvonalakon, amelyek különböző forrásfogalmakra nyúlnak vissza, akkor ebből az is következik, ahogy Heine, Claudi és Hünnemeyer (1991: 38) mondják, hogy egy forrásfogalom különböző konceptualizációs útvonalakon keresztül többféle irányba grammatikalizálódhat. Heine és Kuteva (2004) lexikonja nem csak olyan forrásfogalmakat gyüjt össze egy grammatikai kategóriához, amelyekböl az adott kategória a világ nyelveiben kimutathatóan származtatható, hanem ennek alapján rendszerezi azt is, hogy milyen grammatikalizációs szerteágazó útvonalak vezethetnek az

3 Ugyanez az eredete az angol shall segédigének, amelyet a brit angol a will segédigétől megkülönböztetve még használ az egyes és többes szám 1. személyben a jövő idő kifejezésére. 
Győri Gábor \& Hegedüs Irén:

A metonímia és a metafora mint a perspektivikus kategorizáció formái a lexikalizációban és a grammatikalizációban

Argumentum 17 (2021), 275-293

Debreceni Egyetemi Kiadó

DOI: $10.34103 / A R G U M E N T U M / 2021 / 15$

egyes grammatikai célkategóriákhoz. Azonban az ilyen esetekben gyakran a szemantikai rekonstrukció is problémát jelenthet, mert az egy forrásalakból történő hangtani levezethetőség ellenére az egy jelentésből való származtatás kérdéses lehet.

Egy ilyen eset például az angol some 'valamiféle; néhány' és same 'ugyanaz' determinánsok, valamint az óangol sam- 'fél' prefixum egy forrásfogalomból történő grammatikalizálódásának a problémája. ${ }^{4} \mathrm{~A}$ három grammatikai elem hangtanilag probléma nélkül levezethető az ôsindoeurópai *sem- 'egy' tőből, de a három irányba történő grammatikalizációs jelentésváltozás fogalmi alapjának felderítése már problémásabb. Viszont aZ EGYSÉG/SOKASÁG (UNITY/ MULTIPLICITY) séma alsémáiból (KOLLEKCIÓ (COLLECTION), RÉSZ-EGÉSZ (PART-WHOLE), FOLYTONOS ISMÉTLÉS (ITERATION)) metonimikus kivetítések alapján magyarázhatónak tünik, hogy hogyan konceptualizálható a három célfogalom ugyanazon forrásfogalom alapján (Hegedüs \& Győri 2019). A KOLLEKCIÓ séma a SOKASÁG-ban található egyes individuumok hasonlóságon alapuló EGYSÉG-ét implikálja, és így az 'egy' az összes többi hasonló 'egy'-gyel asszociálható, ami tükröződik a más nyelvekben is használatos 'egy és ugyanaz' kifejezésben. A RÉSZ-EGÉSZ séma azt implikálja, hogy az individuumok SOKASÁG-a egy EGÉSZ-et alkot, amikor a sok 'egy' az EGÉSZ-nek az egyes részeit képezi. Ebbe a konfigurációba beletartozik az a speciális, kiugró eset is, amikor az EGÉSZ-et két azonos RÉSZ, vagyis egy rész meg egy rész (kétszer 'egy', azaz két fél) alkotja, ami alapján az 'egy' a féllel asszociálható. A FOLYTONOS ISMÉTLÉS séma a SOKASÁG létrehozását implikálja az egy-egy individuum meghatározatlan számú, újból és újból történő hozzáadásával, vagyis azt, hogy a SOKASÁG meghatározatlan számú 'egy'-ből áll, és így az 'egy' a meghatározatlan mennyiséggel, valamint általánosságban a meghatározatlansággal asszociálható, vagyis a some determináns két jelentésével.

\section{5 Összefoglalás}

A jelen tanulmányban azt vizsgáltuk, hogy a metaforikus és metonimikus látásmódnak milyen megnyilvánulásai vannak a lexikalizációban és a grammatikalizációban, és ezt különböző nyelvekből vett példák segítségével illusztráltuk. Három különböző perspektivizációt különítettünk el, egyrészt szinkón és diakrón vonatkozásban, másrészt megjelenési formáikat illetően, és megvizsgáltuk ezek különféle összefüggéseit is. A nyelvben megjelenő perspektivikus látásmód legszembeötlöbb formája az, amikor a kifejezések extenziója nyelvek közötti összehasonlításban gyakran szerteágazó eltéréseket mutat. Ez konkrét értelemben a nyelv referenciális használatában mutatkozik meg. A nyelvnek a valóság jelenségeit kategorizáló jellege nem csak a lexikális, hanem a grammatikai elemek vonatkozásában is fennáll. Ennek következtében a világ felosztásában mutatkozó különbségek gyakran a grammatikai elemek konvencionalizálódott használatának is köszönhetők. Így lehet az, hogy például ugyanazon térbeli viszonyokat a különböző nyelvek különbözőképpen láttatják az így kialakult eltérő konceptualizációkon keresztül.

A perspektivizáció az egyes kifejezések szemantikai áttetszőségén keresztül is megnyilvánulhat. Ez azt jelenti, hogy sok kifejezésben megfigyelhető valamilyen metaforikus vagy metonimikus látásmód, amely az adott nyelvi elem létrejöttének konceptualizációs alapjául szolgált. Az erről árulkodó szemantikai áttetszőség többnyire csak a lexikális elemekben tettenérhető, mivel a grammatikai elemek túlnyomó többsége kialakulásuk során mind szemantikailag,

4 Az óangol sam-prefixum etimológiai rokona az azonos jelentésủ görög hemi- és latin semi- prefixumoknak. Az angolban ma már csak dialektusokban maradt fenn. 
Györi Gábor \& Hegedüs Irén:

A metonímia és a metafora mint a perspektivikus kategorizáció formái a lexikalizációban és a grammatikalizációban

Argumentum 17 (2021), 275-293

Debreceni Egyetemi Kiadó

DOI: 10.34103/ARGUMENTUM/2021/15

mind alakilag olyan változásokon ment keresztül, amelyek elhomályosítják a bennük rejlő metaforikus vagy metonimikus perspektívát. Ezekben az esetekben azonban a nyelvi elem létrejöttében szerepet játszó történeti szemantikai folyamatok feltárásával kaphatunk információt arról, hogy milyen konceptualizációk befolyásolták kialakulásukat. Tehát mind a lexikális, mind a grammatikai elemek etimológiai vizsgálata általában egyfajta történeti szemantikai áttetszőséget tükröz, amely sokat elárul az adott lexikalizációs és grammatikai folyamat során megfigyelhető metaforikus és metonimikus konceptualizációban megjelenő perspektívá ról. Az így felderített különböző lexikalizációs és grammatikalizációs útvonalak gyakran magyarázattal is szolgálhatnak arra, hogy a szinkrón szempontból szószerinti jelentéssel bíró lexémák és a grammatikai elemek a funkcionális jelentésük által miért kategorizálják a világ jelenségeit még percepciós alapokon is eltérö módon a világ nyelveiben. Az etimológiai vizsgálatokban az is megfigyelhetö nyelvek közötti összehasonlításban, hogy ugyanazon fogalmak lexikalizációja gyakran különböző konceptualizációk útján jött létre, és fordítva, hogy hasonló vagy ugyanolyan perspektíva alapján történő konceptualizációk végül különböző fogalmak lexikalizációjához vezettek. Ez a kétfajta alternatív konceptualizációs folyamat a grammatikalizációban is megjelenik, amikor azonos grammatikai funkciók kialakulásának különböző fogalmak adják a konceptualizációs alapját, illetve különböző grammatikai jelentéseknek ugyanazon fogalmak a történeti forrásai.

\section{Szótárak}

Duden Online: https://www.duden.de/woerterbuch

MNyÉSz = A Magyar Nyelv Értelmezö Szótára I-VII. Szerk. Bárczi Géza és Országh László. Budapest: Akadémiai Kiadó, 1959-1962.

OED Online = Oxford English Dictionary, 2021. Oxford University Press. www.oed.com

The American Heritage Dictionary. Boston: Houghton Mifflin, 2011.

TESz = A magyar nyelv történeti-etimológiai szótára I-IV. Szerk. Benkő Loránd. Budapest: Akadémiai Kiadó, 1967-1984.

Uralonet = Uráli Etimológiai Adatbázis http://www.uralonet.nytud.hu/

\section{Irodalom}

Bárczi, G., Benkő, L. \& Berrár, J. (1967): A magyar nyelv története. Budapest: Tankönyvkiadó. Blank, A. (2003): Words and concepts in time: Towards diachronic cognitive onomasiology. In: Eckardt, R., von Heusinger, K. \& Schwarze, C. (eds.): Words in Time: Diachronic Semantics from Different Points of View. Berlin, New York: Mouton de Gruyter, 37-65. https://doi.org/10.1515/9783110899979.37

Brinton, L. J. \& Traugott, E. C. (2005): Lexicalization and Language Change. Cambridge: Cambridge University Press. https://doi.org/10.1017/CBO9780511615962

Bybee, J. L. (2011): Usage-based theory and grammaticalization. In: Narrog, H. \& Heine, B. (eds.): The Oxford Handbook of Grammaticalization. Oxford: Oxford University Press, 6978. https://doi.org/10.1093/oxfordhb/9780199586783.013.0006

Campbell, L. (1998): Historical Linguistics: An Introduction. Edinburgh: Edinburgh University Press. 
Györi Gábor \& Hegedüs Irén:

A metonímia és a metafora mint a perspektivikus kategorizáció formái a lexikalizációban és a grammatikalizációban

Argumentum 17 (2021), 275-293

Debreceni Egyetemi Kiadó

DOI: 10.34103/ARGUMENTUM/2021/15

Croft, W. (2013): Language use and the evolution of languages. In: Binder, P. \& Smith, K. (eds.): The Language Phenomenon. Berlin: Springer, 93-120.

Croft, W. \& Cruse, A. D. (2004): Cognitive Linguistics. Cambridge: Cambridge University Press. https://doi.org/10.1017/CBO9780511803864

Dér Cs. I. (2019): Grammatikalizáció. Budapest: Akadémiai Kiadó. https://doi.org/10.1556/9 789634544357 (Letöltve: 2021.03.20. https://mersz.hu/hivatkozas/m554g_10_p2\#m554g_ $\left.10 \_\mathrm{p} 2\right)$

Geeraerts, D. (1997): Diachronic Prototype Semantics: A Contribution to Historical Lexicology. Oxford: Clarendon Press.

Gibson, J. J. (1979): The Ecological Approach to Visual Perception. Boston, MA: Houghton Mifflin.

Goodson, F. E. (2003): The Evolution and Function of Cognition. Hillsdale, NJ: Lawrence Erlbaum Associates.

Győri, G. (1996): Historical aspects of categorization. In: Casad, E. (ed.): Cognitive Linguistics in the Redwoods: The Expansion of a New Paradigm in Linguistics. Berlin, New York: Mouton de Gruyter, 175-206. https://doi.org/10.1515/9783110811421.175

Győri, G. (2002): Semantic change and cognition. Cognitive Linguistics 13.2, 123-166. https://doi.org/10.1515/cogl.2002.012

Győri, G. (2005): The adaptive nature of 'meaning as understanding'. Acta Linguistica Hungarica 52.2, 199-220. https://doi.org/10.1556/ALing.52.2005.2-3.4

Györi, G. (2017): What happens to the basic level in language? Some theoretical considerations with cross-linguistic examples. Cognitive Linguistic Studies 4.2, 171-193. https://doi.org/10.1075/cogls.00001.gyo

Győri, G. \& Hegedüs, I. (2012): A cognitive approach to the methodology of semantic reconstruction: The case of English chin and knee. In: Allen, K. \& Robinson, J. A. (eds.): Current Methods in Historical Semantics. Berlin, Boston: De Gruyter Mouton, 313-333. https://doi.org/10.1515/9783110252903.313

Hampton, J. A. (2006): Concepts as prototypes. In: Ross, B. H. (ed.): The Psychology of Learning and Motivation. San Diego: Academic Press, 79-113. https://doi.org/10.1016/S0079$\underline{7421(06) 46003-5}$

Harder, P. \& Boye, K. (2011): Grammaticalization and functional linguistics. In: Narrog, H. \& Heine, B. (eds.): The Oxford Handbook of Grammaticalization. Oxford: Oxford University Press, 56-68. https://doi.org/10.1093/oxfordhb/9780199586783.013.0005

Harnad, S. (2005): To cognize is to categorize: Cognition is categorization. In: Cohen, H. \& Lefebvre, C. (eds.): Handbook of Categorization in Cognitive Science. Amsterdam: Elsevier, 20-43. https://doi.org/10.1016/B978-008044612-7/50056-1

Hegedüs, I. \& Györi, G. (2019): Uncovering historical semantic connections with the help of image schemata: The case of Modern English some, same and Old English sam-. Cognitive Linguistic Studies 6.1, 1-21. https://doi.org/10.1075/cogls.00028.heg

Heine, B., Claudi, U. \& Hünnemeyer, F. (1991): Grammaticalization: A Conceptual Framework. Chicago: The University of Chicago Press.

Heine, B. \& Kuteva, T. (2004): World Lexicon of Grammaticalization. Cambridge: Cambridge University Press.

Jackendoff, R. (1991): Parts and boundaries. Cognition 41, 9-45. https://doi.org/10.1016/0010$\underline{0277(91) 90031-X}$ 
Győri Gábor \& Hegedüs Irén:

A metonímia és a metafora mint a perspektivikus kategorizáció formái a lexikalizációban és a grammatikalizációban

Argumentum 17 (2021), 275-293

Debreceni Egyetemi Kiadó

DOI: $10.34103 / A R G U M E N T U M / 2021 / 15$

Johnson, M. (1987): The Body in the Mind: The Bodily Basis of Meaning, Imagination, and Reason. Chicago, London: The University of Chicago Press. https://doi.org/10.7208/chicago/9780226177847.001.0001

Kövecses, Z. (2005): Metaphor in culture: Universality and Variation. Cambridge: Cambridge University Press. https://doi.org/10.1017/CBO9780511614408

Kövecses, Z. (2017): The Hungarian root es- in language and cognition. Language and Cognition 9.1, 121-155. https://doi.org/10.1017/langcog.2015.29

Kövecses, Z. (2020): Extended Conceptual Metaphor Theory. Cambridge: Cambridge University Press. https://doi.org/10.1017/9781108859127

Kövecses, Z. \& Benczes, R. (2010): Kognitív nyelvészet. Budapest: Akadémiai Kiadó.

Kroonen, G. (2013): Etymological Dictionary of Proto-Germanic. Leiden, Boston: Brill.

Lakoff, G. (1987): Women, Fire and Dangerous Things: What Categories Reveal about the Mind. Chicago: The University of Chicago Press. https://doi.org/10.7208/chicago/9780226471013.001.0001

Lakoff, G. (1990): The Invariance Hypothesis: Is abstract reason based on image-schemas? Cognitive Linguistics 1.1, 39-74. https://doi.org/10.1515/cogl.1990.1.1.39

Langacker, R. W. (1987): Foundations of Cognitive Grammar. Volume 1: Theoretical Prerequisites. Stanford, CA: Stanford University Press.

Langacker, R. W. (1991): Foundations of Cognitive Grammar. Volume 2: Descriptive Application. Stanford, CA: Stanford University Press.

Langacker, R. W. (2011): Grammaticalization and Cognitive Grammar. In: Narrog, H. \& Heine, B. (eds.): The Oxford Handbook of Grammaticalization. Oxford: Oxford University Press, 79-91. https://doi.org/10.1093/oxfordhb/9780199586783.013.0007

Langacker, R. W. (2013): Essentials of Cognitive Grammar. Oxford, New York: Oxford University Press.

Mallory, J. P. \& Adams, D. Q. (1997): The Encyclopedia of Indo-European Culture. London, Chicago: Fitzroy Dearborn.

Mark, J. T., Marion, B. B. \& Hoffman, D. D. (2010): Natural selection and veridical perceptions. Journal of Theoretical Biology 266.4, 504-515.

https://doi.org/10.1016/j.jtbi.2010.07.020

Nagy C., K. (2018): Metafora, metonímia és pragmatikai következtetés a grammatikalizációs jelentésváltozásban. Jelentés és Nyelvhasználat 5, 93-116. https://doi.org/10.14232/jeny.2018.1.4

Nerlich, B. \& Clarke, D. D. (1992): Outline of a model for semantic change. In: Kellermann, G. \& Morrissey, M. D. (eds.): Diachrony within Synchrony: Language History and Cognition: Papers from the International Symposium at the University of Duisburg, 26-28 March 1990. Frankfurt am Main: Peter Lang Verlag, 125-141.

Orel, V. (2003): A Handbook of Germanic Etymology. Leiden, Boston: Brill.

Quiatt, D. \& Reynolds, V. (1993): Primate Behaviour: Information, Social Knowledge, and the Evolution of Culture. Cambridge: Cambridge University Press.

Regier, T., Kemp, C., \& Kay, P. (2015): Word meanings across languages support efficient communication. In: MacWhinney, B. \& O'Grady, W. (eds.): The Handbook of Language Emergence. Oxford: Wiley Blackwell, 237-263.

https://doi.org/10.1002/9781118346136.ch11

Rosch, E. H. (1978): Principles of categorization. In: Rosch, E. \& Lloyd, B. B. (eds.): Cognition and Categorization. Hillsdale, NJ: Lawrence Erlbaum Associates, 27-48. 
Györi Gábor \& Hegedüs Irén:

A metonímia és a metafora mint a perspektivikus kategorizáció formái a lexikalizációban és a grammatikalizációban

Argumentum 17 (2021), 275-293

Debreceni Egyetemi Kiadó

DOI: $10.34103 / A R G U M E N T U M / 2021 / 15$

Rosch, E. H., Mervis, C. B., Gray, W. D., Johnson, D. M., \& Boyes-Braem, P. (1976): Basic objects in natural categories. Cognitive Psychology 8.3, 382-439. https://doi.org/10.1016/0010-0285(76)90013-X

Seiler, T. B. (1985): Sind Begriffe Aggregate von Komponenten oder idiosynkratische Minitheorien? In: Seiler, T. B. \& Wannenmacher, W. (eds.): Begriffs- und Wortbedeutungsentwicklung. Berlin: Springer, 105-131. https://doi.org/10.1007/978-3-642-70489-5_5

Singh, M. \& Hoffman, D. D. (2013): Natural selection and shape perception. In: Dickinson, S. J. \& Pizlo, Z. (eds.): Shape Perception in Human and Computer Vision: An Interdisciplinary Perspective. London: Springer, 171-185. https://doi.org/10.1007/978-1-4471-5195-1_12

Tolcsvai Nagy, G. (2013): Bevezetés a kognitív nyelvészetbe. Budapest: Osiris Kiadó.

Tomasello, M. (1999): The Cultural Origins of Human Cognition. Cambridge, MA, London, England: Harvard University Press.

Tomasello, M. (2003): The key is social cognition. In: Gentner, D. \& Goldin-Meadow, S. (eds.): Language in Mind: Advances in the Study of Language and Thought. Cambridge, MA: The MIT Press, 46-57.

Traugott, E. C. (2011a): Pragmatics and language change. In: Allan, K. \& Jaszczolt, K. (eds.): The Cambridge Handbook of Pragmatics. Cambridge: Cambridge University Press, 549565). https://doi.org/10.1017/CBO9781139022453.030

Traugott, E. C. (2011b): Grammaticalization and mechanisms of change. In: Narrog, H. \& Heine, B. (eds.): The Oxford Handbook of Grammaticalization. Oxford: Oxford University Press, 19-30. https://doi.org/10.1093/oxfordhb/9780199586783.013.0002

Traugott, E. C. \& Dasher, R. B. (2002): Regularity in Semantic Change. Cambridge: Cambridge University Press. https://doi.org/10.1017/CBO9780511486500

Wischer, I. (2000): Grammaticalization versus lexicalization: 'Methinks' there is some confusion. In: Fischer, O., Rosenbach, A. \& Stein, D. (eds.), Pathways of Change: Grammaticalization in English. Amsterdam, Philadelphia: John Benjamins, 355-370. https://doi.org/10.1075/slcs.53.17wis

\author{
Dr. Győri Gábor \\ Pécsi Tudományegyetem \\ Anglisztika Intézet, Angol Nyelvészeti Tanszék \\ 7624 Pécs, Ifjúság útja 6. \\ gyori.gabor@pte.hu \\ Dr. Hegedüs Irén \\ Pécsi Tudományegyetem \\ Anglisztika Intézet, Angol Nyelvészeti Tanszék \\ 7624 Pécs, Ifjúság útja 6. \\ hegedus.iren@pte.hu
}

